\title{
Chalk depth structure maps, Central to Eastern North Sea, Denmark
}

\author{
Ole V. Vejbæk, Torben Bidstrup, Peter Britze, Mikael Erlström, Erik S. Rasmussen and Ulf Sivhed
}

The Upper Cretaceous - Danian chalk may be considered to be the economically most important rock type in Denmark. Onshore it constitutes an important groundwater aquifer and it is also quarried for e.g. building materials and paper production. Offshore the chalk reservoirs contain more than $80 \%$ of the oil and gas produced in Denmark (Fig. 1).

During the last few years efforts have therefore been made to map this important succession in the Danish and adjoining areas (Vejbæk et al. 2003). The stratigraphic interval mapped comprises the Chalk Group of Cenomanian to Danian ages and its stratigraphically equivalent units (Fig. 2). The north-eastern limit of the Chalk Group is determined by Neogene erosion. The limits of the map to the west and south were mainly determined by the amount of available data.

\section{Data base}

The comprehensive data base comprises high-resolution and conventional 2-D and 3-D reflection seismic data as well as published maps (e.g. Britze et al. 1995; Hommel 1996; Ottesen et al. 1997; Jensen 1998; Kramarskiej 1999; Balds- chuhn et al. 2001; Stoker 2005). More than 500 deep wells and numerous onshore water wells have provided control for the mapping. This is especially relevant for the mapping where the Top Chalk is immediately overlain by the Neogene (Fig. 3). In these areas in particular, mapping was based on high-resolution seismic data.

\section{Depth conversion}

Depth conversion was undertaken by using depth-dependent velocity functions, where the velocity $V$ at depth $z$ is given by:

$$
V=V_{o}+d V+K \times z
$$

where $V_{o}$ is the surface velocity, $d V$ is a variation of the surface velocity and $K$ is the gradient of velocity increase with depth (Table 1; e.g. Japsen 1998, 1999). The surface velocity variation is typically mapped on the basis of well data and may reflect lateral facies changes, burial anomalies or excess fluid pressures.

Fig. 1. Hydrocarbon accumulations in the North

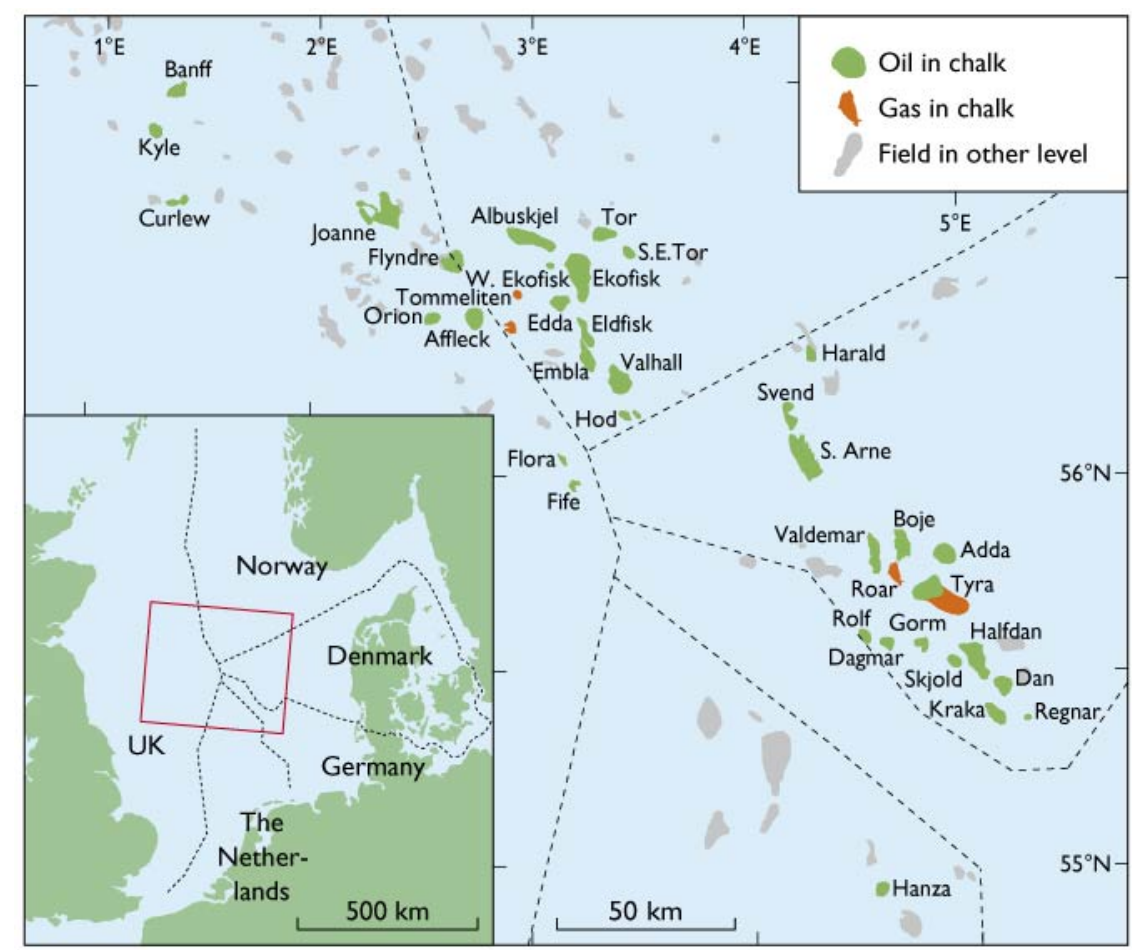




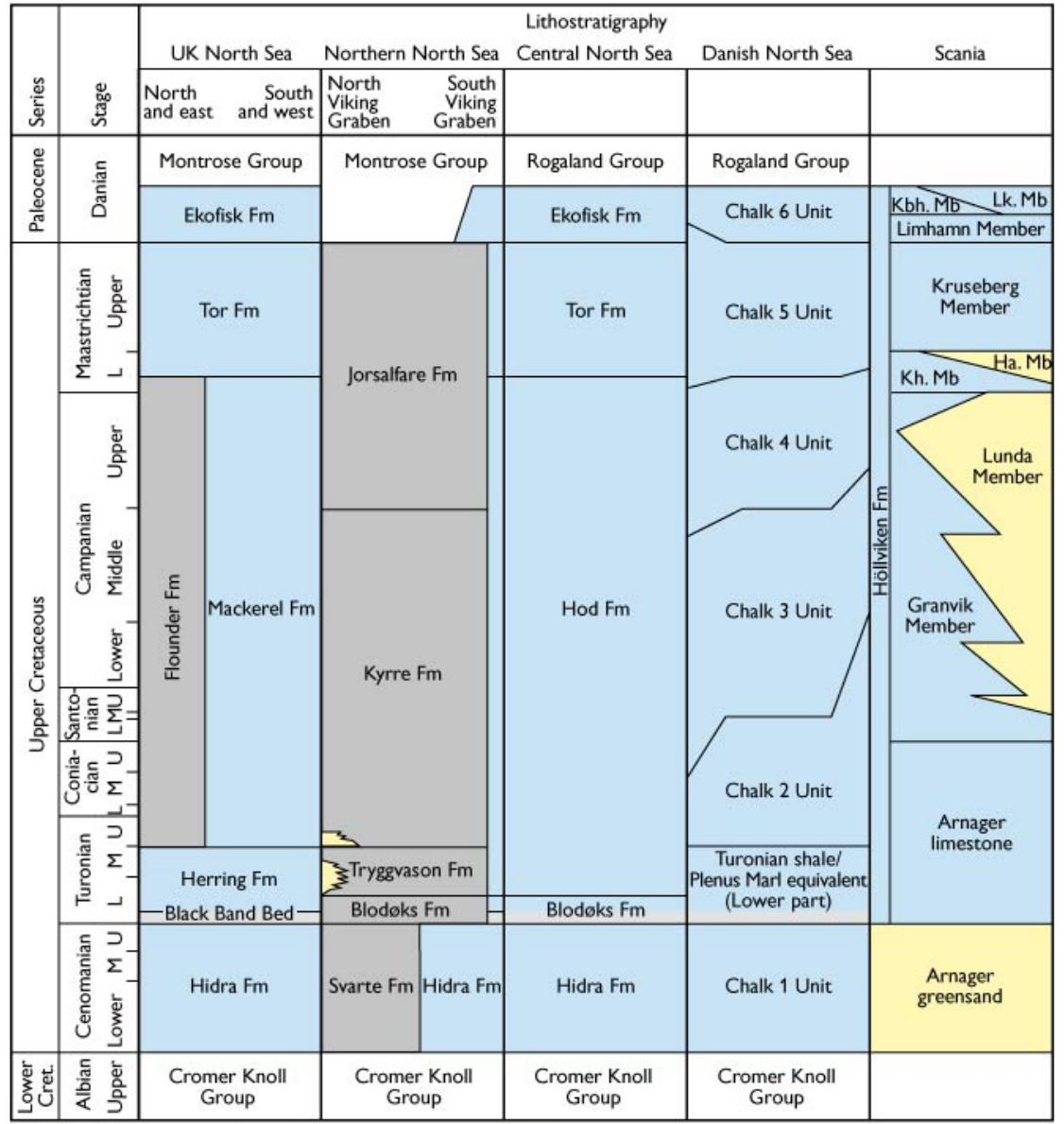

Chalk Group

Fig. 2. Lithostratigraphic correlation for the Upper Cretaceous - Danian succession as mapped in this paper. Based on Deegan \& Scull (1977), Isaksen \& Tonstad (1989), Johnson \& Lott (1993) and Schiøler et al. (2007) with additions modified from Surlyk et al. (2003) and Sivhed et al. (1999).

Ha. Mb, Hansa Member;

Kbh. Mb, København Member;

Kh. Mb, Kyrkheddinge Member;

Lk. Mb, Landskrona Member.

\section{Notes about the maps}

In some areas where the Neogene lies directly on the Top Chalk seismic horizon, the erosional truncation of the Chalk Group is negligible. This occurs around Copenhagen, in northern Sjælland and in south-western Scania, where minor outliers of Selandian deposits document the former extent of the Chalk Group. The occurrence of Palaeogene sediments offshore Poland also indicates that erosion of the Chalk Group is generally not very deep in the

The Cenozoic velocity model consists of a single layer onshore Denmark and two layers offshore. The division between the two layers is taken at the 'near Top Middle Miocene marker' that corresponds approximately to the top of the over-pressured section (Upper and Lower Post Chalk Group in Table 1). The parameters for these layers were taken from Britze et al. (1995) and Japsen (1999, 2000) who derived a similar but segmented model for the Chalk Group. Since the parameters are based on a large well data base from the entire North Sea (e.g. Japsen 2000), they are applicable to most of the North Sea.

Table 1. Parameters for depth conversion

\begin{tabular}{lccl}
\hline Unit & $V_{0}(\mathrm{~m} / \mathrm{sec})$ & $\mathrm{K}\left(\mathrm{sec}^{-1}\right)$ & Source \\
\hline Upper Post Chalk Group & 1725 & 0.4 & Britze et al. 1995 \\
Lower Post Chalk Group & 1517.2 & 0.6 & Japsen et al. 1999 \\
Chalk $\mathrm{z}<900 \mathrm{~m}$ & 1550 & 1.3 & Japsen 2000 \\
Chalk $900 \mathrm{~m}<\mathrm{z}<1471$ & 920 & 2 & Japsen 2000 \\
Chalk $1471 \mathrm{~m}<\mathrm{z}<2250$ & 1950 & 1.3 & Japsen 2000 \\
Chalk $2250 \mathrm{~m}<\mathrm{z}<2875$ & 2625 & 1 & Japsen 2000 \\
\hline
\end{tabular}

western Baltic outside the main inversion zones (Fig. 3).

In Norwegian waters, however, extensive Neogene erosion has occurred. The erosion in these areas is sufficiently deep for Lower Cretaceous deposits to subcrop the base of the Neogene. Outside these areas the Chalk Group generally has a larger areal extent than the Lower Cretaceous. (Fig. 3).

A general increase in thickness of the Chalk Group is found west of the Sorgenfrei-Tornquist inversion zone. A north-eastward increase in thickness is also found in the areas unaffected by Neogene erosion offshore southern Norway, suggesting the presence of similar depocentres on the flanks of inversion zones. Thus, inversion may also have occurred in the south-western coastal areas of Norway.

\section{Facing page:}

Fig. 3. Simplified structure maps of the Chalk Group and equivalent deposits. A, depth to top Chalk Group; B, depth to base Chalk Group and $\mathbf{C}$, isopach. Grey shadings in A and $\mathrm{C}$ indicate where the Lower Cretaceous subcrops Quaternary sediments (i.e. where the Chalk Group has been totally removed by erosion). Cph, Copenhagen. PDF versions of the maps with more detail are available from www.geus.dk/publications/bull/nr13/index-uk.htm 

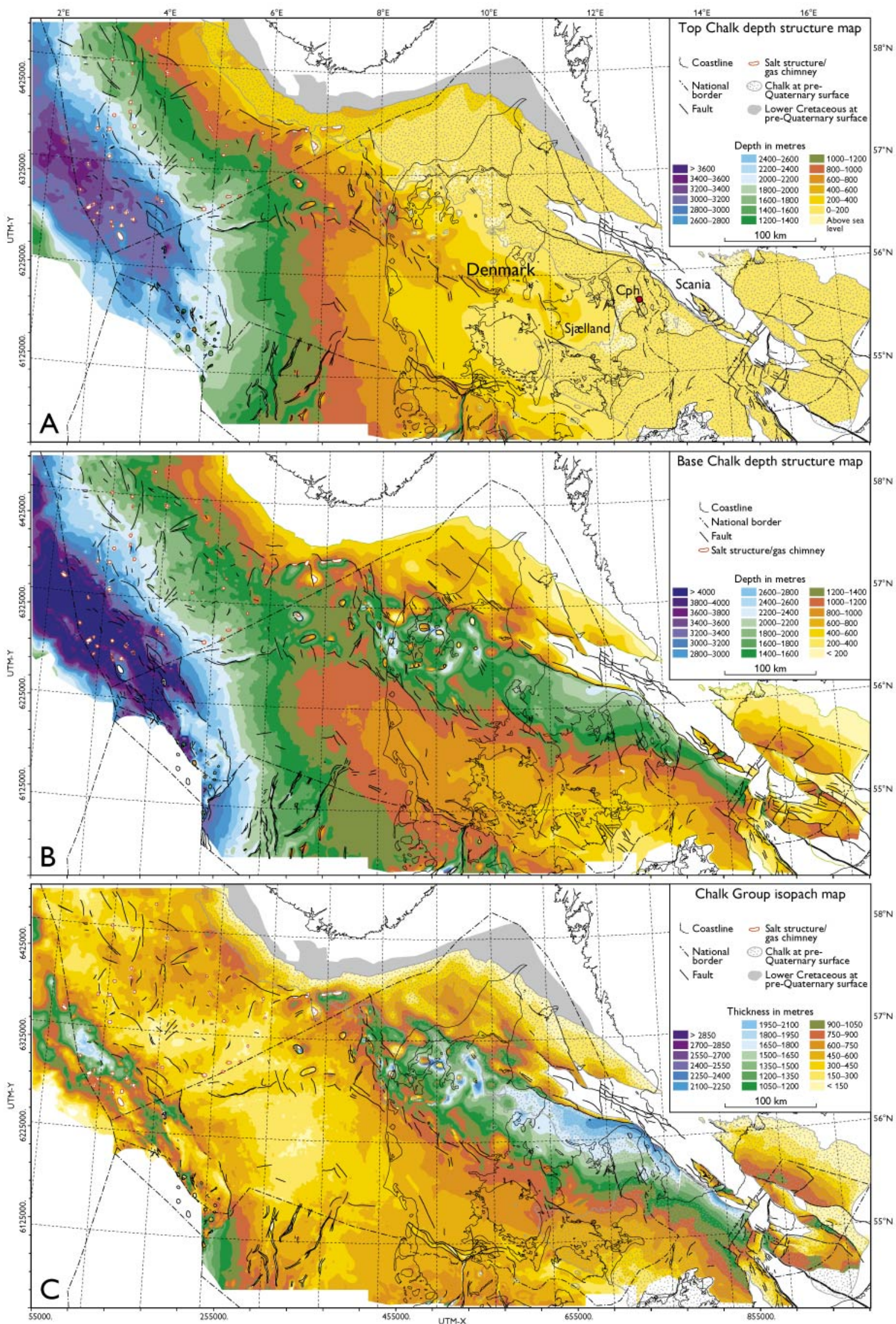


\section{Hydrocarbon aspects}

The Chalk Group in the Central Graben area is an important reservoir and migration path for oil and gas. It is the most important oil-producing interval in Denmark and is also a major contributor to oil and gas production in Norway and the Netherlands, while production from the Chalk Group is still insignificant in the UK sector (Fig. 1). Traps within the Chalk Group range from inversion-generated anticlines (e.g. the Valhall, Roar, Tyra and South Arne fields), over salt domes with some degree of inversion overprint (e.g. the Dan, Ekofisk and Svend fields) to salt diapirs (e.g. the Skjold and Harald fields). Stratigraphic traps may also play a major role (e.g. the Halfdan and Adda fields). These traps owe their existence to a combination of over-pressuring and early hydrocarbon invasion to preserve the quality of their reservoirs despite the great depths to which they have been buried (e.g. Anderson 1999; Vejbæk in press). Their position directly above the main Upper Jurassic source rock also seems to be a necessary condition for their existence (e.g. Anderson 1999; Surlyk et al. 2003), since the generally very low permeability of the chalk precludes long-distance migration and even keeps accumulations in hydrodynamic dis-equilibrium (e.g. Dennis et al. 2005; Vejbæk et al. 2005).

\section{References}

Anderson, J.K. 1999: The capabilities and challenges of the seismic method in chalk exploration. In: Fleet, A.J. \& Boldy, S.A.R. (eds): Petroleum geology of Northwest Europe. Proceedings of the 5th conference, 939-947. London: Geological Society.

Baldschuhn, R., Binot, F., Fleig, S. \& Kockel, F. 2001: Geotektonischer Atlas von Nordwest-Deutschland und dem deutschen Nordsee-Sektor. Geologisches Jahrbuch Reihe A 153, 88 pp. + 3 CD-ROMs.

Britze, P., Japsen, P. \& Andersen, C. 1995: The Danish Central Graben: Top Chalk and the Post Chalk Group. Two-way travel time and depth and interval velocity, 1:200 000. Geological Survey of Denmark Map Series $\mathbf{4 7}, 5$ pp. +3 maps.

Deegan, C.E. \& Scull, B.J. 1977: A proposed standard lithostratigraphic nomenclature for the Central and Northern North Sea. Report of the Institute of Geological Sciences $\mathbf{7 7 / 2 5}, 35$ pp. (also published as Norwegian Petroleum Directorate Bulletin 1).

Dennis, H., Bergmo, P. \& Holt, T. 2005: Tilted oil-water contacts: modelling effects of aquifer heterogeneity. In: Doré, A.G. \& Vining, B.A. (eds): Petroleum geology: North-West Europe and global perspectives. Proceedings of the 6th petroleum geology conference, 145-158. London: Geological Society.

Hommel, V. 1996: Structural evolution of the Rønne-Kolobrzeg Graben area. Unpublished M.Sc. thesis, 82 pp. University of Copenhagen, Denmark.
Isaksen, D. \& Tonstad, V. 1989: A revised Cretaceous and Tertiary lithostratigraphic nomenclature for the Norwegian North Sea. Norwegian Petroleum Directorate Bulletin 5, 59 pp.

Japsen, P. 1998: Regional velocity-depth anomalies, North Sea Chalk; a record of overpressure and Neogene uplift and erosion. American Association of Petroleum Geologists Bulletin 82, 2031-2074.

Japsen, P. 1999: Overpressured Cenozoic shale mapped from velocity anomalies relative to a baseline for marine shale, North Sea. Petroleum Geoscience 5, 321-336.

Japsen, P. 2000: Fra kridthav til Vesterhav, Nordsøbassinets udvikling vurderet ud fra seismiske hastigheder. Geologisk Tidskrift 2002/2, 36 pp.

Jensen, S.K. 1998: Structural development of the Sorgenfrei-Tornquist Zone and adjacent areas, Norwegian North Sea Sector. Unpublished M.Sc. thesis, 88 pp. University of Aarhus, Denmark.

Johnson, H. \& Lott, G.K. 1993: Cretaceous of the Central and Northern North Sea. In: Knox, R.W. O'B. \& Cordey, W.G. (eds): Lithostratigraphic nomenclature of the UK North Sea, 2, 169 pp. Nottingham: British Geological Survey.

Kramarskiej, R. (ed.) 1999: Geological map of the Baltic Sea bottom without Quaternary deposits, 1: 500 000. Gdansk-Warszawa: Panstwowy Instytut Geologiczny.

Ottesen, D., Bøe, R., Longva, O., Olsen, H. A., Rise, L., Skilbrei, J. R. \& Thorsnes, T. 1997: Geologisk atlas - Skagerrak. Atlas over kvartære avleiringer, bunnsedimenter, berggrunn og batymetri i norsk sektor av Skagerrak. Norges Geologiske Undersøkelse Rapport 96.138, 55 pp.

Schiøler, P. et al. 2007: Lithostratigraphy of the Palaeogene - Lower Neogene succession of the Danish North Sea. Geological Survey of Denmark and Greenland Bulletin 12, 77 pp.

Sivhed, U., Wikman, H. \& Erlström, M. 1999: Beskrivning till berggrundskartorna 1C Trelleborg NV och SO samt 2C Malmö SV, SO, NV och NO. (SGU Serie Af 191, 192, 193, 194, 196, 198, skala 1:50 000). Uppsala: Sveriges Geologiska Undersökning, 143 pp.

Stoker, S. 2005: Chalk play of the UK Central Graben, 11 pp. Department of Trade and Industry Workshop, Aberdeen, 23 November, 2005. Poster (available on: http://www.og-mrp.com/dissemination/workshops/ukcs/Posters/UKCS_Chalk_Play_BGS.pdf).

Surlyk, F., Dons, T., Clausen, C.K. \& Higham, J. 2003: Upper Cretaceous. In: Evans, D. et al. (eds.): The millennium atlas: petroleum geology of the central and northern North Sea, 213-233. London: Geological Society.

Vejbæk, O. in press: On dis-equilibirium compaction as the cause for the Cretaceous-Paleogene over-pressures in the Danish North Sea. American Association of Petroleum Geologists Bulletin.

Vejbæk, O.V., Bidstrup, T., Britze, P., Erlström, M., Rasmussen, E.S. \& Sivhed, U. 2003: Chalk structure maps of the Central and Eastern North Sea. Danmarks og Grønlands Geologiske Undersøgelse Rapport 2003/106, 55 pp.

Vejbæk, O.V., Frykman, P., Bech, N. \& Nielsen, C.M. 2005: The history of hydrocarbon filling of Danish Chalk field. In: Doré, A.G. \& Vining, B.A. (eds): Petroleum geology: North-West Europe and global perspectives. Proceedings of the 6th petroleum geology conference, 1331-1346. London: Geological Society.

\section{Authors' addresses}

O.V.V., T.B., P.B. \& E.S.R., Geological Survey of Denmark and Greenland, Øster Voldgade 10, DK-1350 Copenhagen K, Denmark. E-mail: ov@geus.dk M.E. \& U.S., Sveriges Geologiska Undersökning, Kiliansgatan 10, S-223 50, Lund, Sweden. 